\title{
Reading Jeremiah 31:31-34 in Light of Deuteronomy 29:21-30:10 and of Inqolobane Yesizwe: Some Remarks on Prophecy and the Torah $^{1}$
}

\author{
NDIKHO MTSHISELWA (UNISA)
}

\begin{abstract}
This article examines the prophetic themes of inclusion, equality and covenantal relationship found in Jer 31:31-34 in a South African context. Set against some of the Dtr themes found in Deut 29:21-30:10 and the DtrN texts in the Book of Jeremiah, Jer 31:31-34 re-iterates prophetic themes which attained an authoritative status in the post-exilic period. The essay therefore argues that whilst the Dtr scribes imposed the normativity of the Torah on the Book of Jeremiah, Jer 31:31-34 articulates the importance of prophecy. Based on an African worldview, the article probes the relevance of the prophetic themes of inclusion, equality and covenantal relationship found in the biblical texts in the South African context. Inqolobane Yesizwe (A Garner of the Nation), which consists of a collection of Zulu wise sayings, proverbs, traditions and histories, provides the context for the African worldview. The essay argues that the text of Jer 31:31-34 would enjoy a possible reception among the Zulu people in South Africa if read in tandem with Inqolobane Yesizwe.
\end{abstract}

KEYWORDS: Jeremiah, Deuteronomy, Deuteronomistic History, Torah and Prophecy, inclusion, equality, covenantal relationship, South Africa

\section{A INTRODUCTION}

There is consensus among OT scholars that the Book of Jeremiah underwent a process of Deuteronomistic (Dtr) redaction which is confirmed by the number of cross-references between the book and the Dtr History. It is purported that the emphasis that the Dtr scribes placed on the importance and normativity of

* Article submitted: 27/10/2017; peer-reviewed: 17/03/2017; accepted: 26/05/2017. Ndikho Mtshiselwa, "Reading Jeremiah 31:31-34 in Light of Deuteronomy 29:2130:10 and of Inqolobane Yesizwe: Some Remarks on Prophecy and the Torah,” Old Testament Essays 30/2 (2017): 403-420, doi: http:// dx.doi.org/10.17159/2312-3621 /2017/v30n2a13

1 This article commemorates the scholarship of Izak J. J. Spangenberg in the field of Old Testament studies. 
law in the Persian period relegated prophecy to an insignificant status. ${ }^{2}$ That the word תִּרוֹרה "Torah” appears 12 times in the Book of Jeremiah (Jer 2:8; 6:19; $8: 8 ; 9: 13 ; 16: 11 ; 18: 18 ; 26: 4 ; 31: 33 ; 32: 11 ; 44: 10 ; 44: 23)$ suggests that the Dtr scribes tried to uphold the importance of the Torah. Said differently, the Dtr edition of the Book of Jeremiah elevated the Torah. Given Römer's thesis that the Book of Jeremiah exhibits a Dtr influence, one wonders whether the entire book contains Dtr themes. Thus, a cardinal question to pose is: does the Book of Jeremiah contain prophetic themes that contradict those found in Dtr texts? If that is the case, as I am inclined to believe, one may argue that although the Dtr scribes elevated the Torah in the Persian period, some texts in the Book of Jeremiah contain prophetic themes which stand in discontinuity with the Dtr themes. To illustrate the preceding hypothesis, the text of Jer 31:31-34 will be examined alongside Deut 29:21-30:10 and other Dtr texts found in the Book of Jeremiah with a specific interest in the prophetic themes of inclusion, equality and covenantal relationship. The point that these themes are also found in the South African context renders Jer 31:31-34 a relevant text among the Zulu people.

Worthy of note is the trend of employing indigenous proverbs to interpret ancient texts among some South African biblical scholars. Using her bosadi approach to the ancient biblical text, Masenya (Ngwan'a Mphahlele) demonstrates how Sotho proverbs could be utilised to interpret biblical proverbs. $^{3}$ Similarly, Mtshiselwa argues that indigenous presuppositions, ideologies and worldviews that are embedded in Xhosa narratives, idioms and proverbs could be employed as a point of reference in interpreting ancient texts. ${ }^{4}$ In the light of such African interpretive approaches to Scriptures, as well as based on Spangenberg's idea of incorporating new paradigms of reading ancient texts into the historical-critical method, ${ }^{5}$ this paper employs the African worldview that is embedded in the Inqolobane Yesizwe as a point of reference in interpreting the text of Jeremiah. Thus, the relevance to the South African context of prophetic themes such as inclusion and equality, which are found in

2 Thomas Römer, “Deuteronomistic History,” EBR: 650.

3 Madipoane Masenya (Ngwan'a Mphahlele), "Between Unjust Suffering and the 'Silent' God: Job and HIV/AIDS Sufferers in South Africa," Miss 29 (2001): 186-199; Madipoane Masenya (Ngwan'a Mphahlele), “A Bosadi (Womanhood) Reading of Proverbs 31:10-31," in Other Ways of Reading: African Women and the Bible, ed. Musa W. Dube (Atlanta: Society of Biblical Literature / Geneva: WCC Publications, 2001), 145-157; Cf. Rasiah S. Sugirtharajah, “Thinking about Vernacular Hermeneutics Sitting in a Metropolitan Study,” in Vernacular Hermeneutics, ed. Rasiah S. Sugirtharajah (Sheffield: Sheffield Academic Press, 1999), 100.

4 Ndikho Mtshiselwa, "Towards an Indigenous (Xhosa) South African Biblical Scholarship,” OTE 24 (2011): 671.

5 Izak J. J. Spangenberg, "Reading the Old Testament in the 21st Century using the Book of Jonah as Reference,” VetE 34 (2013): 1-7. 
the Jer 31:31-34 will be probed. The Inqolobane Yesizwe (A Garner of the Nation), which consists of a collection of Zulu wise sayings, proverbs, traditions and histories, serves as the context for the African worldview. The hypothesis of this article states that the prophetic themes of inclusion, equality and covenantal relationship found in Jer 31:31-34 would enjoy a positive reception among the Zulu of South Africa.

\section{B COMPOSITION AND REDACTION OF THE BOOK OF JEREMIAH}

Whilst it is widely accepted that the Book of Jeremiah underwent a Dtr redaction, the prophetic themes of inclusion, equality and covenantal relationship found in Jer 31:31-34 seem to be in contrast with the Dtr themes contained in Deut 29:21-30:10 and some of the Dtr texts cited in the Book of Jeremiah. That is, some texts in the Book of Jeremiah contradict the themes of the Dtr redactor. Before outlining the contradictions, a discussion on the composition and redaction of the Book of Jeremiah is in order. My interest here lies in illustrating the influence of the Dtr scribes in the production of the Book of Jeremiah.

\section{The Influence of Deuteronomistic Scribes}

For Römer, "There is no doubt that of the three Major Prophets, Jeremiah is the most 'Deuteronomistic' book." Stackert agrees that the book of Jeremiah exhibits both theological and literary ties to Dtr texts. ${ }^{7}$ As will be shown below, Dtr scribes set the agenda for the Book of Jeremiah, as Dtr themes appear to be dominant in the book. The point that the Book of Jeremiah was composed and edited in the Persian period by the scribes belonging to the Dtr circle accounts for the noticeable ties between the Dtr text and Jeremiah. Also, the evident number of cross-references and parallels between the Book of Jeremiah and some texts in the Dtr History supports the view that the Book of Jeremiah was redacted by the Dtr scribes. ${ }^{8}$ It is therefore necessary to identify the Dtr layers in the Book of Jeremiah. In an attempt to distinguish the Dtr layers, Römer shows that:

6 Thomas Römer, "The Redaction of Three Great Prophets as a Reaction to the Crisis of Babylonian Exile,” ITS 50 (2013): 259.

7 Jeffrey Stackert, "Mosaic Prophecy and the Deuteronomic Source of the Torah," in Deuteronomy in the Pentateuch, Hexateuch and the Deuteronomistic History, ed. Raymond F. Person, Jr., and Konrad Schmid, FAT II/56 (Tübingen: Mohr Siebeck, 2012), 62.

8 Thomas Römer, "The Formation of the Book of Jeremiah as a Supplement to the So-Called Deuteronomistic History," in The Production of Prophecy: Constructing Prophecy and Prophets in Yehud, ed. Diana V. Edelman and Ehud Ben Zvi (London: Equinox, 2009), 168; Römer, “Deuteronomistic,” 652. 
The so-called "model of Gottingen" (where Smend taught) is therefore characterized by the distinction of three Dtr layers: DtrH (the "historian," responsible for the first edition of DtrH, who writes during the exile), DtrP (a prophetic Deuteronomist, only found in Samuel-Kings) and DtrN (a nomistic Dtr, who at the end of the exilic or the beginning of the Persian period insists on the importance of the law). ${ }^{9}$

By implication, any material edited by the DtrN scribes in the post-exilic period would stress the importance of the Torah above certain literary genres, in particular, prophecy. In such a case, prophecy therefore would be placed at the margins, while the Torah is elevated. Schmid explains how the normativity of the Torah developed, which could shed light on how the Torah was elevated in the history of ancient Israel at the expense of prophecy. He notes that because "there was no central law within the Persian Empire (539-331 BCE)," people had to live according to their own laws and rules. ${ }^{10}$ Since the formation of the Torah was probably rooted in Persian imperialism, the Judeans chose to live according to the Torah. The Torah therefore gained its normative status. Schmid further reasons that:

The "Torah" as the basic document of ancient Judaism clearly functions as a normative text per se, demanding personal submission and obedience (see e.g. Deut 30:1-14) ... Its authority is not backed by the king but is inherent to it as a normative text claiming divine. ${ }^{11}$

The normativity of the Torah inspired its dominance and perhaps to some extent its superiority. From an ideological point of view, the law (cf. Deut 30:1-14) became more significant than prophecy especially in respect of the prophetic themes of inclusion, equality and covenantal relationship found in Jer 31:31-34. The emphasis on the Torah in the Book of Deuteronomy and in some texts of the Dtr History was thus imported to the Book of Jeremiah. This may be demonstrated by teasing out cross-references between the books under consideration.

9 Römer, “Deuteronomistic,” 650.

10 Konrad Schmid, "The Genesis of Normativity in Biblical Law: Historical and Theological Observations on the Development of the Canonical Notion of Law in the Hebrew Bible and Its Applications on Nature,” in Concepts of Law in the Sciences, Legal Studies, and Theology, ed. Michael Welker and Gregor Etzelmüller (Tübingen: Mohr Siebeck, 2013), 125.

11 Schmid, “Genesis of Normativity,” 121. 
Mtshiselwa, “Reading Jeremiah 31:31-34,” OTE 30/2 (2017): 403-420

Cross-References between the Books of Jeremiah and Deuteronomy and the Dtr History

The number of cross-references between the Book of Jeremiah and the Dtr History supports the view that the book underwent a process of Deuteronomistic (Dtr) editing. ${ }^{12}$ One may further argue that such cross-references confirm both the influence of the DtrN scribes and the elevation of the Torah in the Book of Jeremiah. Limited by the scope of this paper, this article focuses on the textual relations between 2 Kgs 22-23 and Jer 36 as well as between Deut 18 (34) and Jer 1.

First, the link between 2 Kgs 22-23 and Jer 36 elicits two related ideas the end of prophecy during the Persian period and the rise of the written text in its stead. ${ }^{13}$ These ideas resonate with the possibility that the Torah was elevated whilst prophecy was set at the margins. Furthermore, an intertextual reading of 2 Kgs 22-23 and Jer 36 suggests that a prophet could no longer operate without the book. Said differently, the prophetic word was no longer autonomous, but dependent on the Torah, ${ }^{14}$ which means that the prophetic themes in the Book of Jeremiah are presented alongside the law as having their origin in DtrN themes. If Jer 36 is indeed the story of the replacement of the prophet by the scribe, the idea of the end of prophecy during the Persian period and the rise of the Torah in its place would make sense. However, as will be shown below, the idea of the end of prophecy and the rise of the Torah does not correspond with some redacted layers of the Book of Jeremiah.

Römer argues that the prophets and their books can most fittingly be viewed as sequel to the Torah, as 2 Kgs 22 and Jer 36 suggest. ${ }^{15}$ That is, prophecy is of secondary importance to the Torah. As will be explained later, I am skeptical about agreeing completely with Römer's argument because there are instances in the Book of Jeremiah where prophecy seems to counter the Torah. Nonetheless, Jer 36 portrays a Jeremiah who is neither a visionary (as in 1:4-9; 24) nor a messenger of divine oracles. Instead, he is presented as the prototype of a "senior scribe" who "dictates to another scribe the words to be written on a scroll." 16 In fact, any word uttered by Jeremiah in this instance would become "the production, property and power of the scribe." ${ }^{17}$ Furthermore, 2 Kgs 22-23

\footnotetext{
12 Römer, “Formation,” 168; Römer, “Deuteronomistic,” 652.

13 Römer, "Formation,” 178.

14 Römer, “Formation,” 177.

15 Thomas Römer, "From Prophet to Scribe: Jeremiah, Huldah and the Invention of the Book," in Writing the Bible: Scribes, Scribalism and Script, ed. Philip R. Davies and Thomas Römer (Durham: Acumen Publishing, 2013), 95.

16 Römer, "From Prophet to Scribe,” 89-90.

17 Robert P. Carroll, "Manuscripts Don’t Burn - Inscribing the Prophetic Tradition: Reflections on Jeremiah 36," in Dort Ziehen Schiffe Dahin: Collected Communica-
} 
reveals that the Book of the Law, that is, the Torah, became a substitute for the Temple, and 2 Kgs 23 is more explicit in that it shows that Josiah replaced the statues and cultic objects after reading the Book. This textual evidence suggests that the Book replaced the sanctuary. A critical question to pose is: Did the Torah replace prophecy? Interestingly, unlike in 2 Kgs 22-23, in Jer 36, the socalled Book replaced the prophet. Instead of presenting a prophet with a prophetic voice, namely, with divine exhortation to the community, in v. 2, the DtrN scribes presents YHWH's instruction: "Take a scroll of a book and write on it all the words that I have spoken to you against Israel and Judah and all the nations..." (Jer 36:2). ${ }^{18}$

Regarding the parallels between Jer 26:2-3 and Jer 36:2-3, it is clear that the scroll took the place of the prophetic voice. ${ }^{19}$ In this instance, the Torah became more important than prophecy. Jeremiah 36 suggests that, "Jeremiah cannot reach the king except through the scribe and the book, and when Jehoiakim, unlike Josiah, burns the book, a new edition is produced, with the help of Baruch." ${ }^{20}$ Having been replaced by scribe and Book, Jeremiah now vanishes from his book. ${ }^{21}$ The point that the prophet could not reach the figure of authority except through the scribe shows the extent of the influence of the DtrN scribes during the redaction of the Book of Jeremiah. The rise of the DtrN scribes accorded the Torah its status of normativity.

The relation of Moses to Jeremiah also supports the view that the themes of the DtrN scribes are discernable in the Book of Jeremiah. Most commentators agree that there is a parallel between Moses and Jeremiah particularly with reference to Deut 18 (34) and Jer $1 .{ }^{22}$ However, there is no

tions to the XIVth Congress of the International Organization for the Study of the Old Testament, ed. Matthias Augustin and Klaus-Dietrich Schunck (Frankfurt am Main: Peter Lang, 1996), 40; Römer, “Formation,” 178.

18 Römer, "From Prophet to Scribe," 90.

19 Römer, "From Prophet to Scribe," 91.

20 Römer argues that, in this instance, the conclusion of ch. 36 no doubt reflects the editing of the prophetic scroll in its various stages. Römer, "From Prophet to Scribe," 91.

21 Römer, "From Prophet to Scribe,” 91.

22 Eckart Otto, "Der Pentateuch im Jeremiabuch: Oberlegungen zur Pentateuchrezeption im Jeremiabuch anhand Neuerer Jeremia-Literatur," ZABR 12 (2006): 245-306; Konrad Schmid, "The Late Persian Formation of the Torah: Observations on Deuteronomy 34," in Judah and the Judeans in the Fourth Century B.C.E., ed. Oded Lipschits, Gary N. Knoppers, and Rainer Albertz (Winona Lake: Eisenbrauns, 2007), 236-245; Römer, “Formation,” 168-183; Stephen L. Cook, “Those Stubborn Levites: Overcoming Levitical Disenfranchisement," in Levites and Priests in History and Tradition, ed. Mark A. Leuchter and Jeremy M. Hutton (Atlanta: Society of Biblical Literature, 2011), 155-170; Stackert, "Mosaic Prophecy," 47-63; Diana V. Edelman, "Introduction," in Deuteronomy-Kings as Emerging 
consensus on the nature of that parallel. The depiction of Moses as the prophet above all prophets (cf. Deut 34:10) forms part of the so-called "Torah conscious" motifs. ${ }^{23}$ However, Otto claims that Jer 1 , for instance, is set against Deut 34 because it shows that Jeremiah was a prophet like Moses. ${ }^{24}$ Although there are resemblances between Moses and Jeremiah in that both may be classified as "true prophets," there is however no compelling reason to equate Jeremiah with Moses. ${ }^{25}$ With respect to the resemblances, like Moses, Jeremiah fits the DtrN characteristics of a "true prophet." Jeremiah's oracles of judgement are also fulfilled (cf. Deut 18:20; Jer 1:16). ${ }^{26}$ Additionally, Deut 18:15-20 shows that a "true prophet" is a preacher of the Torah. This criterion is equally noticeable in Jer 9:12; 26:4; 44:10 of the MT. Thus, Jeremiah can be viewed as a prophet like Moses. However, the DtrN texts equally insinuate that Moses was incomparable to other prophets.

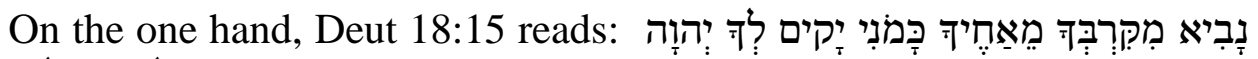

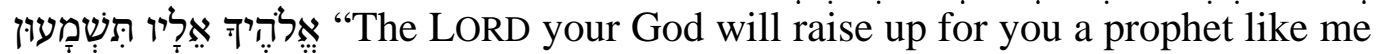
from among your own brothers. You must listen to him.” On the other hand,

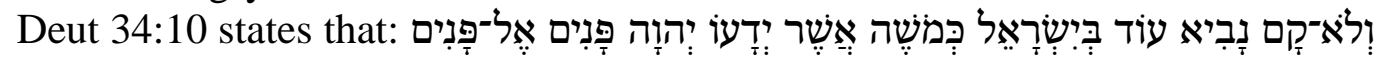
"Since then, no prophet has risen in Israel like Moses, whom the LORD knew face to face.” Schmid explains the discrepancy between Deut 34:10 and Deut 18:15 as follows:

The reason is most likely to be found in the need to break apart the chain of prophetic succession starting with Moses. Whereas Deut 18:15 envisions such a succession between Moses as archprophet and his successors, Deut 34:10 wants to separate Moses from all other prophets. The reason for this separation between "Moses" and the "prophets" is most easily found in the formation of Torah: Moses has to be separated from the prophets as soon as the Torah is seen as superior to the Prophets (i.e. the prophetic books Joshua - Malachi as section of the canon referred to as "Prophets"). ${ }^{27}$

Authoritative Books: A Conversation, ed. Diana V. Edelman (Atlanta: Society of Biblical Literature, 2014), 1-26; Jeffrey Stackert, A Prophet Like Moses: Prophecy, Law and Israelite Religion (Oxford: Oxford University Press, 2014).

23 Schmid, "Late Persian Formation," 247.

24 Deuteronomy 34:10 says, "Never since had arisen a prophet like Moses, whom Yahweh knew face to face.” Otto, "Pentateuch im Jeremiabuch,” 245-306.

25 Römer, "Formation," 173.

26 Carolyn J. Sharp, Prophecy and Ideology in Jeremiah: Struggles for Authority in Deutero-Jeremianic Prose (London: T \& T Clark, 2003), 158; Römer, "Formation," 172-173; Römer, "Redaction of Three," 258.

27 Schmid, “Late Persian Formation,” 248. 
The reference to the Torah partly explains the view that Moses was incomparable to other prophets, including Jeremiah. If the Torah was to gain any dominance, the person who is most related to it, namely, Moses would be placed justifiably above other prophets. Stackert also supports the view that Moses was above all other prophets because the Mosaic prophecy is distinct: "According to Num 12, God communicates with other prophets through visions and dreams, but he speaks directly - face to face - with Moses." 28 The argument confirms the legitimisation of Moses. If Moses, the so-called lawgiver, "was the last Israelite prophet, after which the law he mediated became normative," it would seem that the elevation and subsequent legitimization of Moses was in fact the legitimisation of the Torah. ${ }^{29}$ Given that that Moses received the law from God, the Torah is legitimised in the Pentateuch and given an authoritative status.

From the investigation of the composition and redaction of the Book of Jeremiah, it is clear that the DtrN scribes influenced the production of the Book of Jeremiah in the post-exilic period. The argument that the DtrN scribes imported the emphasis on the Torah made in the Book of Deuteronomy and in some texts of the Dtr History to the Book of Jeremiah is therefore conclusive. Römer's argument that the Book of Jeremiah, among other prophetic books, can most fittingly be viewed as sequel to the Torah would also make some sense. No doubt, the influence of the DtrN scribes is noticeable in the Book of Jeremiah but the text of Jeremiah also refutes the Dtr themes. The point that Jer 31:31-34 appears to contradict Deut 29:21-30:10 necessitates the comparison of the two texts.

\section{COMPARISON OF JEREMIAH 31:31-34 AND DEUTERONOMY 29:21-30:10}

If the Dtr edition of Jeremiah placed more emphasis on the Torah and less on prophecy, then, it is worth noting that Jer 31:31-34 is set against Deut 29:2130:10 and some of the Dtr texts in the Book of Jeremiah. As Fischer has noted, the Book of Jeremiah is dependent on the Book of Deuteronomy. ${ }^{30}$ However, against Fischer and Römer's observation, Christian claims that, "the manner in which Jeremiah texts differ and distance themselves from parallel texts in Deuteronomy suggests a debate between law and prophecy occurring in

\footnotetext{
28 Stackert, “Mosaic Prophecy,” 50.

29 Stackert, Prophet Like Moses, 34; cf. Edelman, “Introduction,” 5.

30 George Fischer, "Der Einfluss des Deuteronomiums auf das Jeremiabuch," in Deuteronomium: Tora für Eine Neue Generation, ed. Georg Fischer, Dominik Markl, and Simone Paganini, BZABR 17 (Wiesbaden: Harrassowitz Verlag, 2011), 248-252.
} 
postexilic Israel, perhaps in the late Persian period." ${ }^{31}$ If there is any credence in Christian's claim, as one is inclined to believe, it means that what we have in Jer 31:31-34 and Deut 29:21-30:10 is a case where the text of Jeremiah refutes the themes associated with the DtrN scribes which are evident in the Book of Deuteronomy.

Interestingly, Jer 31:31-34 suggests that, "the Pentateuchal theory of a transcription of the Torah by Moses in Exodus 24:4 and Deut 31:932 was refuted by the prophetic theory of a divine transcription of the Torah on the people's

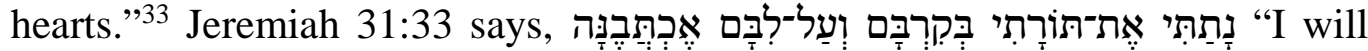
put my law in their minds and write it on their hearts.” The perfect qal verb "נָתתחתי "I will put” which is presented in the first person singular clearly confirms that in this instance, it was YHWH who gave the people the Torah. Otto's view that Jer 31:31-34 formed a counter-position to the transcription of the Torah by Moses found in the book of Deuteronomy is therefore decisive. Furthermore, the negative particle, לה "no or not" which is presented alongside the plural

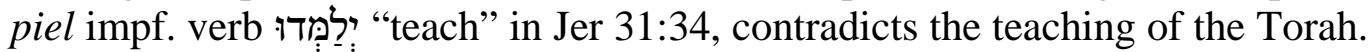
Such a teaching would be invalid and unnecessary, as the Torah would be internalised by all the people. Thus, Otto's view that "the Pentateuchal ideas of teaching and learning the Mosaic Torah (Deut 6:6-7, 20-25; 11:18-21; 31:1213) were refuted" in Jer 31:34 makes sense. ${ }^{34}$ Since Deut 30:10 also exhibits such ideas, it is reasonable to argue that Jer 31:31-34 is set against Deut 29:2130:10.

Jeremiah 31:31-34 refers to "a new covenant" (cf. v. 31) which presupposes the invalidation of the old covenant. Moses introduced the old covenant in Deut 5:1 with an imperative verb in the singular, שֵַׁׁ "hear." 35 The verb is rendered in the plural form in Jer 11:2, where it is used to summon people to hear the words of the covenant. Clearly, Jer 11:2 acknowledges the Mosaic covenant but in Jer 31:31, "the Pentateuchal idea of a Mosaic covenant at Sinai and Horeb as the only covenants was overcome by the idea that there would be a new covenant." 36 The idea of a new covenant contrasts with the old Mosaic covenant which is contained in some of the Jeremiah texts. Interestingly, "the new regime nonetheless presupposes the continuing validity

31 Mark Christian, review of Deuteronomium: Tora für eine neue Generation, ed. Georg Fischer, Dominik Markl, and Simone Paganini, RBL 7 (2013), online: http://www.bookreviews.org/pdf/8416_9217.pdf.

32 Compare Deut 6:9; 10:2; 17:18; 27:3, 8.

33 Eckart Otto, “Torah and Prophecy: A Debate of Changing Identities," VetE 34 (2013): 3.

34 Otto, "Torah and Prophecy," 3.

35 Cook, "Those Stubborn Levites," 158.

36 Otto, "Torah and Prophecy,” 3. 
of divine law."37 Instead of completely rejecting the old covenant, YHWH would still maintain a form of the covenant which counters the idea of doom.

Not only is Jeremiah's announcement of doom a critical factor in the argument that Moses is parallel to Jeremiah, the announcement is also key in the recognition of the influence of the DtrN scribes in the Book of Jeremiah. However, the announcement of doom is omitted in Jer 31:31-34. The Dtr description of Jeremiah as the last prophet of doom does not cover all the passages in the Book of Jeremiah (cf. Jer 1:16; 9:12; 11:2; 26:4; 44:10). Jeremiah 30:31-34 opposes the Dtr idea of doom by "announcing a new covenant and a time or restoration."38 The text of Deut 29:21, “And the LORD would separate him from all the tribes of Israel for adversity, according to all the curses of the covenant that are written in this Book of the Law," may be regarded as a prophecy of doom. The reference to the "plagues of that land and the sicknesses which the LORD has laid” (Deut 29:22) equally alludes to a prophecy of doom. However, such a prophecy of doom is clearly omitted in Jer

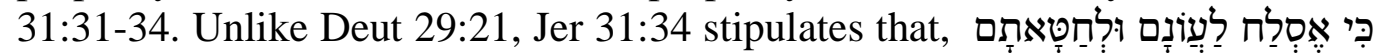
כ"For I will forgive their wickedness and will remember their sins no more.” The theme of restoration of the relationship between God and people which is typical of the Priestly authors (P) contrasts with the prophecy of doom contained in the Book of Deuteronomy and in the Dtr texts in Jeremiah. ${ }^{39}$

The covenantal relationship between YHWH and the people refutes the idea of a "Deity/Moses-people" relationship which according to Otto denotes the elevation of a human being to the level of a deity. ${ }^{40}$ The Dtr authors elevated Moses to the level of a deity (Deut 7:4-11; 11:13-15), ${ }^{41}$ That elevation is also noticeable in Deut 30:1-2:

When all these blessings and curses I have set before you come upon you and you take them to heart wherever the LORD your God disperses you among the nations, and when you and your children

37 Bernard M. Levinson, "You Must not Add Anything to What I Command You: Paradoxes of Canon and Authorship in Ancient Israel," Numen 50 (2003): 23-24.

38 Thomas Römer, "Moses, Israel's First Prophet, and the Formation of the Deuteronomistic and Prophetic Libraries," in Israelite Prophecy and the Deuteronomistic History: Portrait, Reality, and the Formation of a History, ed. Mignon R. Jacobs and Raymond F. Person, Jr. (Atlanta: Society of Biblical Literature, 2013), 140.

39 Christophe Nihan, From Priestly Torah to Pentateuch: A Study in the Composition of the Book of Leviticus (Tübingen: Mohr Siebeck, 2007), 361-382; Römer, "Redaction of Three," 256.

40 Eckart Otto, "The Book of Deuteronomy and Its Answer to the Persian State Ideology: The Legal Implications," in Loi et Justice dans la Littérature du ProcheOrient Ancien, ed. Olivier Artud, BZABR 20 (Wiesbaden: Harrassowitz, 2013), 114115.

41 Otto, “Book of Deuteronomy,” 114-115, 120. 
return to the LORD your God and obey him with all your heart and with all your soul according to everything I command you today.

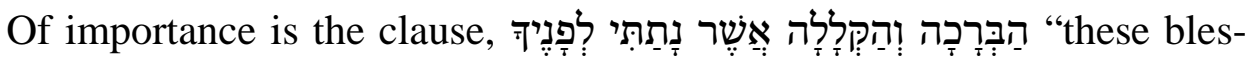

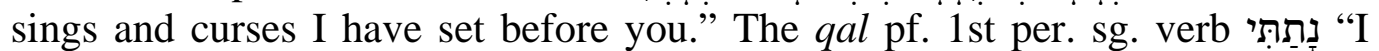
have set" suggests that Moses was addressing the people because in the same verse, he referred to יהוֹה אֶלֶֶיף: "YHWH Elohim.” The point in this text is that Moses was the giver of blessings and curses. YHWH no longer assumed that role, Moses did. In addition, Moses is presented as the one who issued commands (Deut 30:2). Logically, it is assumed that the people would obey the person who issued the command. However, the second person form used in the

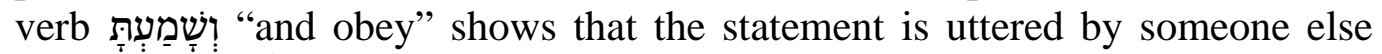
other than יהוֹה אלֶֶיף: "YHWH Elohim.” A deity is the one who should be

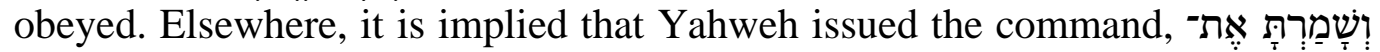

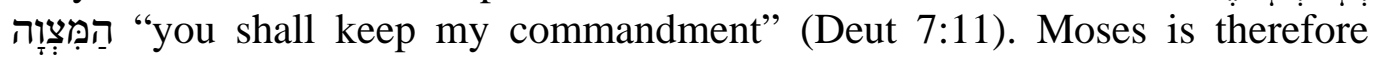
elevated to the level of a deity who typically issues commands for people to obey. However, and most importantly, the "Deity/Moses-people” relationship is not assumed in Jer 31:31-34. The point that YHWH would place the covenant inside people's hearts relegates Moses from the level of a deity. The nature of the covenantal relationship between YHWH and the people in Jer 31:31-34 shows that Moses is not featured.

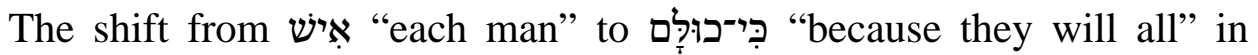
Jer 31:34 is also noteworthy. The tone of inclusion in the statement "because they will all know me" contrasts with that of exclusion which is observed in "the segregationist ideology of parts of the Babylonian Golah."42 Deuteronomy

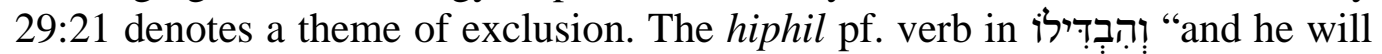
separate him" 43 implies the theme of exclusion or segregation in the preceding text. However, Deut 30:5a presupposes that the Jews in the Babylonian exile would return to possess the land of their ancestors. Also, v. 5b promised the Judean returnees economic prosperity whilst the people who remained in the land were excluded from the possession of the land and the subsequent prosperity. Unlike, Jer 37-43, Jer 31:31-34 portrays a Jeremiah who supports the people who remain in the land. ${ }^{44}$ The theme of inclusion is therefore set as a counter-theme to that of exclusion which is evident in Deut 29:21-30:10 as well as in the Dtr texts in the Book of Jeremiah such as Jer 29.

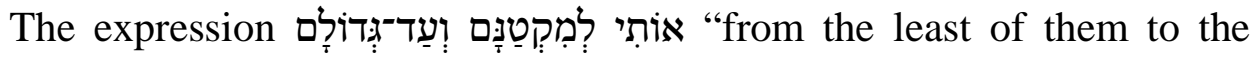
greatest” in Jer 31:34 suggests that people were being treated equally. The new covenantal community envisioned in Jer 31:31-34 upholds the theme of equality which refutes the notion of discrimination that is based on social class.

42 Römer, "Deuteronomistic," 652.

43 The present hiphil verb may also be translated as "divide."

44 Römer, "Moses," 140. 
The idea of equality may be read in contrast to the Dtr notion of inequality contained in the books of Jeremiah and Deuteronomy. For instance, an allusion to being uprooted from the land due to YHWH's anger in Deut 29:28 presupposes unequal possession of the economic resources between the élite returnees from exile and the Judeans who remained in the land. The returnees had money and the support of the Persian leadership. ${ }^{45}$ In light of the reference to the possession of land (Deut 30:5), Knight's compelling argument that in the postexilic period the large portions of agricultural land which produced wealth were owned by the rich and powerful élites is also noteworthy. ${ }^{46}$ Based on the observation by both Meyer and Knight that the élite returnees from exile were wealthy, it is reasonable to argue that Deut 29:21-30:10 also exhibits traces of inequality which highlights the gap between the poor and the rich. Jeremiah 31:34 thus espouses the idea of equality which in turn shows resistance to and disapproval of inequality.

Against the argument that what we have in the Book of Jeremiah is the elevation of the Torah, it may be argued that the prophetic themes of inclusion, equality and covenantal relationship were equally important especially in the post-exilic period. The point that Jer 31:31-34 is an integral part of the "book of consolation” (Trostbüchlein), namely Jer 30-31, accords the themes of inclusion, equality and covenantal relationship an authoritative status. ${ }^{47}$ It would be interesting to examine whether these themes have any relevance in the South African context. One also wonders whether Jer 31:31-34 could be more appealing in such a context compared to Deut 29:21-30:10 and some DtrN texts in the Book of Jeremiah and more importantly in the light of Inqolobane Yesizwe.

\section{JEREMIAH 31:31-34 IN LIGHT OF INQOLOBANE YESIZWE - ANY RELEVANCE TO ZULU PEOPLE?}

Based on an African worldview, the relevance of the themes of inclusion, equality and covenantal relationship found in the biblical text to the South African context is probed in what follows. The concept of Inqolobane Yesizwe (A Garner of the Nation), which consists of a collection of Zulu wise sayings,

\footnotetext{
45 Esias E. Meyer, The Jubilee in Leviticus 25: A Theological Ethical Interpretation from a South African Perspective (Münster: LIT Verlag, 2005), 253.

46 Douglas A. Knight, Law, Power and Justice in Ancient Israel (Louisville: Westminster John Knox Press, 2011), 202.

47 Eckart Otto, "Scribal Scholarship in the Formation of Torah and Prophets: A Postexilic Scribal Debate between Priestly Scholarship and Literary Prophecy - The Example of the Book of Jeremiah and its Relation to the Pentateuch,” in The Pentateuch as Torah: New Models for Understanding Its Promulgation and Acceptance, ed. Gary N. Knoppers and Bernard M. Levinson (Winona Lake: Eisenbrauns, 2007), 171-184; Otto, “Torah and Prophecy,” 3.
} 
proverbs, traditions and histories, provides the context for the African worldview.

On the themes of forgiveness and restoration, a Zulu expression, ukukhumelana umlotha, "the sharing of ash," comes to mind. For Mchunu, this expression explains the ritual of cleansing and the reconciliation of two groups or persons. ${ }^{48}$ In Zulu, it is noted, certain proverbs seek to inculcate forgiveness and the restoration of relationships between people. Ntsimane explains that ukukhumelana umlotha is not only a Zulu saying but also one of the conflictresolution tools that are used to reconcile people. ${ }^{49}$ The themes of forgiveness and restoration in Jer 31:31-34, which contrast with the prophecy of doom in the book of Deuteronomy and in the Dtr texts in Jeremiah, resonate with the tenor of forgiveness and reconciliation underlying the proverbial concept of ukukhumelana umlotha. Thus, the Zulu people would identify more readily with Jer 31:31-34 than Deut 29:21-30:10. In the light of the proverbial concept, a call for forgiveness and restoration of relationships would be appealing in the South Africa context, particularly among many Zulus.

If Jer 31:31-34 is read as a rebuttal of the tendency to elevate a human being (e.g. Moses) to the level of a deity, a fitting Zulu proverb that echoes a similar criticism on the elevation of a human being would be Ufaka inyongo nesinya, which is explained as, Uzama ukuzenza mkhulu kunento ayiyo ngempele, "You are attempting to elevate yourself above your level."50 A similar saying, Uthwala ishoba, has the connotation, Uyaziphakamisa, ubukela phansi abanye, "You elevate yourself to the point of looking down on other people." 51 The challenge with one's self-elevation is that it belittles others. Thus, in a context of hierarchical relationships, the proverb, Inkosi yinkosi ngabantu "A chief is a chief through his subjects" is used to denounce ingratitude and the act of belittling other people which often manifests in people with power. ${ }^{52}$ In view of the Zulu proverbs that are against the elevation of a person to a superior level or position, the contrary view of not elevating a human being to the level of a deity in Jer 31:31-34 would be compelling to Zulu people.

48 Mxolisi R. Mchunu, "A History of Political Violence in KwaShange, Vulindlela District and of Its Effects on the Memories of Survivors (1987-2008)," (PhD diss., University of KwaZulu-Natal, 2013), 276.

49 Radikobo Ntsimane, "Violence, Landscape and the Possibilities of Reconciliation in KwaNxamalala in the Province of KwaZulu-Natal," MInt 63/1-2 (2011): 70-78.

50 Sibusiso Nyembezi and Otty E. H. Nxumalo, Inqolobane Yesizwe (Pietermaritzburg: Shuter \& Shooter Publishers, 2008), 145.

51 Nyembezi and Nxumalo, Inqolobane Yesizwe, 145.

52 Sibusiso Nyembezi, Zulu Proverbs (Johannesburg: Witwatersrand University Press, 1954), 61. 
The Zulu saying, ukhetha iphela emasini, "selecting a cockroach in the fermented milk," implies ukubadlulula, "segregation or separation." 53 The saying opposes the exclusion of members of the community, and it shows a striking resemblance to the theme of inclusion which is set against exclusion in Deut 29:21-30:10 as well as in the Dtr texts in Jeremiah. For his part, Wink argues that ubuntu, a concept that is derived from the proverb, Umuntu ngumuntu ngabantu, "A person is a person through other persons," emphasises a sense of togetherness, interdependence and community. ${ }^{54}$ Clearly, in the idea of ubuntu, the separation of others is rejected in favor of inclusivity. Mbaya notes that ubuntu is about interconnectedness and interdependence. ${ }^{55}$ Since, inclusivity and communality are upheld in the concept of ubuntu, that is, specifically, in the Zulu sayings, the theme of inclusion in Jer 31:31-34, which is set against exclusion in Deut 29:21 would appeal to the Zulu people. Interestingly, the concept of Ubuntu is in line with Spangenberg's idea of relations among people. He says, "I have compassion (suffer with others), therefore I am." ${ }^{56}$ For him the idea of being is characterised by being with other people. Interconnectedness with other people therefore defines a person's being and identity. The concept of Ubuntu as well as Spangenberg's idea of "being" is related to Saayman's concept of "being human together."

Saayman interestingly develops the theme of "being human together" based on the maxim, Umuntu ngumuntu ngabantu, "A person is a person through other persons." The theme is opposed to inequality in the South African context, namely, economic, racial, and political inequalities. ${ }^{57}$ Given the tenor of equality underlying the saying, Umuntu ngumuntu ngabantu, the

53 Nyembezi and Nxumalo, Inqolobane Yesizwe, 159.

54 Benjamin E. Winks, "A Covenant of Compassion: African Humanism and the Rights of Solidarity in the African Charter on Human and Peoples' Rights," AHRLJ 11 (2011): 460.

55 Henry Mbaya, "Social Capital and the Imperatives of the Concept and Life of Ubuntu in the South African Context," Scriptura 106 (2011): 6; cf. Augustine Shutte, Ubuntu: An Ethic for a New South Africa (Pietermaritzburg: Cluster Publications, 2001), 12; Madipoane Masenya (Ngwan'a Mphahlele), “An African-Conscious Female Reading of Steve Biko," in The Legacy of Stephen Bantu Biko: Theological Challenges, ed. Cornel W. du Toit (Pretoria: Research Institute for Religion and Theology, University of South Africa, 2008), 124.

${ }^{56}$ Izak J. J. Spangenberg, “'The Poor will always be with you': Wealth and Poverty in a Wisdom Perspective," in Plutocrats and Paupers: Wealth and poverty in the Old Testament, ed. Hendrik L. Bosman, Ig Gous and Izak J. J. Spangenberg (Pretoria: Van Schaik, 1991), 242.

57 Richard Tambulasi and Happy Kayuni, "Can African Feet Divorce Western Shoes? The Case of 'Ubuntu' and Democratic Good Governance in Malawi," NJAS 14 (2005): 154, 156; Willem Saayman, "Being Human Together in Democratic South Africa: Umuntu Ngumuntu Ngabantu,” JGRA 17 (2011): 175, 177. 
contrasting idea of inequality in Jer 31:34 would make sense among the Zulu people. However, it may also be noted that a number of Zulu proverbs, equally perpetuate inequality. The proverb, Ikhanda elixegaxegayo lofulela abafazi, which is explained as, Umthetho wendoda emzini wayo kufanele wenziwe, uthotshelwe "The law of the man in his house must be obeyed" is a fitting example. ${ }^{58}$ This proverb perpetuates gender inequality in the household. Thus, one would agree with Masenya (Ngwan'a Mphahlele) that endorsing ubuntu entails a critic of forms of female oppression and implicitly supporting the liberation of women. ${ }^{59}$

\section{E CONCLUSION}

That the Book of Jeremiah underwent a Dtr redaction process is conclusive. Although the Dtr scribes imposed the normativity of the Torah on the Book of Jeremiah, Jer 31:31-34 elevates prophecy. The composer of Jer 31:31-34 stresses the prophetic themes of inclusion, equality and covenantal relationship which counter the Dtr themes of exclusion, inequality and "Deity/Mosespeople" relationship found in the Book of Deuteronomy. The argument that prophecy was of secondary importance to the Torah in the postexilic period may thus be demystified. The prophetic themes under consideration also received an authoritative status just as the Torah enjoyed normative status. The prophetic themes of inclusion, equality and covenantal relationship found in Jer 31:31-34 became critical restorative themes in the post-exilic period.

On a methodological level, this essay employed an African worldview that is pictured in a collection of Zulu wise sayings, proverbs, traditions and histories, named Inqolobane Yesizwe, as a point of reference for interpreting aspects of the ancient biblical text in the South African context. Read in the light of Inqolobane Yesizwe, the themes of forgiveness and restoration in Jer 31:31-34 which refute the prophecy of doom in the book of Deuteronomy and in the Dtr texts in Jeremiah are significant. Also, it is shown that the argument against the elevation of a human being to the level of a deity in Jer 31:31-34 would be compelling to the Zulu people. The theme of inclusion which contrasts markedly with exclusion in Deut 29:21-30:10 as well as in the Dtr texts in Jeremiah makes sense from the Zulu point of view. Additionally, Zulu people would appreciate the disproval of inequality in Jer 31:34.

\section{BIBLIOGRAPHY}

Carroll, Robert P. “Manuscripts Don’t Burn - Inscribing the Prophetic Tradition: Reflections on Jeremiah 36.” Pages 31-42 in Dort Ziehen Schiffe Dahin:

58 Nyembezi and Nxumalo, Inqolobane Yesizwe, 141.

59 Madipoane Masenya (Ngwan'a Mphahlele), "Without a Voice, with a Violated Body: Re-Reading Judges 19 to Challenge Gender Violence in Sacred Texts,” Miss 40 (2012): 207. 
418 Mtshiselwa, “Reading Jeremiah 31:31-34,” OTE 30/2 (2017): 403-420

Collected Communications to the XIVth Congress of the International

Organization for the Study of the Old Testament. Edited by Matthias Augustin and Klaus-Dietrich Schunck. Frankfurt am Main: Peter Lang, 1996.

Christian, Mark. Review of Deuteronomium: Tora für eine neue Generation, edited by Georg Fischer, Dominik Markl, and Simone Paganini. RBL 7 (2013), 10 pages. http://www.bookreviews.org/pdf/8416_9217.pdf.

Cook, Stephen L. "Those Stubborn Levites: Overcoming Levitical Disenfranchisement.” Pages 155-170 in Levites and Priests in History and Tradition. Edited by Mark A. Leuchter and Jeremy M. Hutton. Atlanta, GA: Society of Biblical Literature, 2011.

Edelman, Diana V. “Introduction.” Pages 1-26 in Deuteronomy-Kings as Emerging Authoritative Books: A Conversation. Edited by Diana V. Edelman. Atlanta, GA: Society of Biblical Literature, 2014.

Fischer, Georg. “Der Einfluss des Deuteronomiums auf das Jeremiabuch.” Pages 274269 in Deuteronomium: Tora für eine neue Generation. Edited by Georg Fischer, Dominik Markl, and Simone Paganini. BZABR 17. Wiesbaden: Harrassowitz Verlag, 2011.

Knight, Douglas A. Law, Power and Justice in Ancient Israel. Louisville, KY: Westminster John Knox Press, 2011.

Levinson, Bernard M. "You Must not Add Anything to What I Command You: Paradoxes of Canon and Authorship in Ancient Israel.” Numen 50 (2003): 1-51.

Masenya (Ngwan'a Mphahlele), Madipoane. "Between Unjust Suffering and the 'Silent' God: Job and HIV/AIDS Sufferers in South Africa.” Missionalia 29 (2001): 186-199.

. “A Bosadi (Womanhood) Reading of Proverbs 31:10-31.” Pages 145-157 in Other Ways of Reading: African Women and the Bible. Edited by Musa W. Dube. Atlanta, GA: Society of Biblical Literature, 2001. . "An African-Conscious Female Reading of Steve Biko.” Pages 114-155 in The Legacy of Stephen Bantu Biko: Theological Challenges. Edited by Cornel W. du Toit. Pretoria: Research Institute for Religion and Theology, University of South Africa, 2008.

. "Without a Voice, with a Violated Body: Re-Reading Judges 19 to Challenge Gender Violence in Sacred Texts.” Missionalia 40/3 (2012): 205216.

Mbaya, Henry. "Social Capital and the Imperatives of the Concept and Life of Ubuntu in the South African Context.” Scriptura 106 (2011): 1-8.

Mchunu, Mxolisi R. "A History of Political Violence in KwaShange, Vulindlela District and of Its Effects on the Memories of Survivors (1987-2008).” PhD diss., University of KwaZulu-Natal, 2013.

Mtshiselwa, Ndikho. "Towards an Indigenous (Xhosa) South African Biblical Scholarship.” OTE 24/3 (2011): 668-689.

Meyer, Esias E. The Jubilee in Leviticus 25: A Theological Ethical Interpretation from a South African Perspective. Münster: LIT Verlag, 2005.

Nihan, Christophe. From Priestly Torah to Pentateuch: A Study in the Composition of the Book of Leviticus. Tübingen: Mohr Siebeck, 2007.

Ntsimane, Radikobo. "Violence, Landscape and the Possibilities of Reconciliation in KwaNxamalala in the Province of KwaZulu-Natal.” MInt 63/1-2 (2011): 70-78. 
Nyembezi, Sibusiso. Zulu Proverbs. Johannesburg: Witwatersrand University Press, 1954.

Nyembezi, Sibusiso and Otty E. H. Nxumalo. Inqolobane Yesizwe. Pietermaritzburg: Shuter \& Shooter Publishers, 2008.

Otto, Eckart. "Der Pentateuch im Jeremiabuch: Oberlegungen zur

Pentateuchrezeption im Jeremiabuch anhand Neuerer Jeremia-Literatur.” ZABR 12 (2006): 245-306.

. "Scribal Scholarship in the Formation of Torah and Prophets: A Postexilic Scribal Debate between Priestly Scholarship and Literary Prophecy - The Example of the Book of Jeremiah and Its Relation to the Pentateuch.” Pages 171-184 in The Pentateuch as Torah: New Models for Understanding Its Promulgation and Acceptance. Edited by Gary N. Knoppers and Bernard M. Levinson. Winona Lake, IN: Eisenbrauns, 2007.

. "The Book of Deuteronomy and Its Answer to the Persian State Ideology: The Legal Implications.” Pages 112-122 in Loi et Justice dans la Littérature du Proche-Orient Ancien. Edited by Olivier Artud. BZABR 20. Wiesbaden: Harrassowitz, 2013. $1-5$. . "Torah and Prophecy: A Debate of Changing Identities.” VetE 34/2 (2013):

Römer, Thomas. "The Formation of the Book of Jeremiah as a Supplement to the Socalled Deuteronomistic History.” Pages 168-183 in The Production of Prophecy: Constructing Prophecy and Prophets in Yehud. Edited by Diana V. Edelman and Ehud Ben Zvi. London: Equinox, 2009.

. "Deuteronomistic History." Pages 648-653 in Encyclopedia of the Bible and Its Reception. Edited by Sebastian Fuhrmann, Gary S. Helft and Anne-Kathrin Runte. Berlin: Walter De Gruyter, 2013.

. "From Prophet to Scribe: Jeremiah, Huldah and the Invention of the Book." Pages 86-96 in Writing the Bible: Scribes, Scribalism and Script. Edited by Philip R. Davies and Thomas Römer. Durham: Acumen Publishing, 2013. . "The Redaction of Three Great Prophets as a Reaction to the Crisis of Babylonian Exile.” ITS 50 (2013): 253-268.

. "Moses, Israel's First Prophet, and the Formation of the Deuteronomistic and Prophetic Libraries.” Pages 129-146 in Israelite Prophecy and the Deuteronomistic History: Portrait, Reality, and the Formation of a History. Edited by Mignon R. Jacobs and Raymond F. Person, Jr. Atlanta, GA: Society of Biblical Literature, 2013.

Saayman, Willem. "Being Human Together in Democratic South Africa: Umuntu Ngumuntu Ngabantu.” JGRA 17/1 (2011): 170-188.

Schmid, Konrad. "The Late Persian Formation of the Torah: Observations on Deuteronomy 34." Pages 236-245 in Judah and the Judeans in the Fourth Century B.C.E. Edited by Oded Lipschits, Gary N. Knoppers, and Rainer Albertz. Winona Lake, IN: Eisenbrauns, 2007. . "The Genesis of Normativity in Biblical Law: Historical and Theological Observations on the Development of the Canonical Notion of Law in the Hebrew Bible and Its Applications on Nature.” Pages 119-136 in Concepts of Law in the Sciences, Legal Studies, and Theology. Edited by Michael Welker and Gregor Etzelmüller. Tübingen: Mohr Siebeck, 2013. 
Sharp, Carolyn J. Prophecy and Ideology in Jeremiah: Struggles for Authority in Deutero-Jeremianic Prose. New York: T \& T Clark, 2003.

Shutte, Augustine. Ubuntu: An Ethic for a New South Africa. Pietermaritzburg: Cluster Publications, 2001.

Spangenberg, Izak J. J. “'The Poor will always be with you’: Wealth and Poverty in a Wisdom Perspective.” Pages 228-246 in Plutocrats and Paupers: Wealth and poverty in the Old Testament. Edited by Hendrik L. Bosman, Ig Gous and Izak J. J. Spangenberg. Pretoria: Van Schaik, 1991.

. "Reading the Old Testament in the 21st Century using the Book of Jonah as Reference.” VetE 34/2 (2013): 1-7.

Stackert, Jeffrey. "Mosaic Prophecy and the Deuteronomic Source of the Torah." Pages 47-63 in Deuteronomy in the Pentateuch, Hexateuch and the Deuteronomistic History. Edited by Raymond F. Person, Jr., and Konrad Schmid. FAT II/56. Tübingen: Mohr Siebeck, 2012. . A Prophet Like Moses: Prophecy, Law and Israelite Religion. Oxford: Oxford University Press, 2014.

Sugirtharajah, Rasiah S. "Thinking about Vernacular Hermeneutics Sitting in a Metropolitan Study.” Pages 92-115 in Vernacular Hermeneutics. Edited by Rasiah S. Sugirtharajah. Sheffield: Sheffield Academic Press, 1999.

Tambulasi, Richard and Happy Kayuni. "Can African Feet Divorce Western Shoes? The Case of 'Ubuntu' and Democratic Good Governance in Malawi.” NJAS 14/2 (2005): 147-161.

Winks, Benjamin E. "A Covenant of Compassion: African Humanism and the Rights of Solidarity in the African Charter on Human and Peoples' Rights.” AHRLJ 11 (2011): 447-464.

Prof. Ndikho Mtshiselwa, Department of Biblical and Ancient Studies, University of South Africa. Email: mtshivnn@unisa.ac.za. 